\title{
KUALITAS VIRGIN COCONUT OIL (VCO) YANG DIBUAT PADA METODE PEMANASAN BERTAHAP SEBAGAI MINYAK GORENG DENGAN PENAMBAHAN WORTEL (Daucus carrota L.)
}

\author{
Megawati Nodjeng ${ }^{1)}$, Feti Fatimah ${ }^{1)}$, Johnly A. Rorong ${ }^{1)}$ \\ ${ }^{1)}$ Program Studi Kimia FMIPA Universitas Sam Ratulangi \\ Jl. Kampus Unsrat, Manado 95115 \\ e-mail: Megawatinodjeng@gmail.com; Fetysanusi@yahoo.com; Rorongjohnly@yahoo.co.id
}

\begin{abstract}
ABSTRAK
Telah dilakukan penelitian untuk mengetahui kualitas VCO yang diolah dengan metode pemanasan dengan adanya penambahan wortel (VCO-wortel) sebagai minyak goreng serta perbandingan kualitasnnya dengan VCO tanpa penambahan wortel (VCO), minyak sawit komersial dan minyak kelapa komersial. Parameter kualitas yang akan di uji yaitu kadar air, asam lemak bebas, bobot jenis dan bilangan peroksida. Hasil penelitian menunjukan VCO-wortel dan minyak kelapa komersial mempunyai kualitas yang lebih baik pada sebelum serta setelah penggorengan pengujian dilakukan terhadap kentang beku sebanyak tiga kali. Hasil diuji statistik dengan Anova. dibandingkan dengan VCO dan minyak sawit komersial. Walaupun nilai asam lemak (FFA) bebas dan bobot jenis minyak kelapa komersial lebih baik daripada VCO-wortel namun tidak ada perbedaan yang signifikan sehingga pembuatan VCO wortel dapat memberi pengaruh yang baik terhadap kualitas VCO sebagai minyak goreng.
\end{abstract}

Kata Kunci : Asam lemak bebas, Bobot jenis dan bilangan peroksida, VCO-Wortel

\section{THE QUALITY OF VIRGIN COCONUT OIL ( VCO ) MADE IN GRADUAL HEATING METHODS AS THE COOKING OIL WITH ADDITION CARROT (Daucus Carrota L.)}

\begin{abstract}
Research has been conducted to determine the quality of the VCO is processed by heating method with the addition of carrots ( VCO - carrots ) as well as comparison kualitasnnya cooking oil with VCO without the addition of carrots ( VCO ), a commercial palm oil and coconut oil commercial. Quality parameters will be tested the moisture content, free fatty acid, peroxide type and weight. The results showed VCO - commercial carrot and coconut oil has a better quality before and after frying tests conducted on frozen potatoes three times . Results were tested statistically by Anova. compared with VCO and commercial palm oil . Although the value of fatty acids ( FFA ) and free weights commercial coconut oils are better than VCO - carrots but no significant difference thus making carrot VCO can give a good effect on the quality of the VCO as a cooking oil .
\end{abstract}

Keywords : Free fatty acids, Weight and type of peroxide, VCO-Carrots

\section{PENDAHULUAN}

Virgin coconut oil (VCO) sebagai minyak goreng merupakan salah satu kebutuhan pokok manusia, namun penggunaan minyak yang berulang-ulang dapat menurunkan kualitas minyak tersebut. Ada masyarakat yang menggunakan minyak goreng hanya untuk satu kali pakai, namun ada juga masyarakat yang menggunakan minyak goreng untuk berkali-kali pakai.
Salah satu alternatif dalam meningkatkan kualitas, aktivitas serta tingkat penerimaan konsumen terhadap VCO adalah dengan menambahkan bahan alam yang mengandung komponen fungsional. Salah satu bahan alam tersebut adalah buah dan rempah-rempah.

Penambahan bahan alam ke dalam VCO dengan tujuan meningkatkan kualitas salah satunya telah diteliti oleh Gugule dan Fatimah (2010) dengan menggunakan 
kemanggi, pala, dan laos yang penggunaan bahan-bahan ini dapat meningkatkan kualitas VCO. Gugule dan Fatimah (2010) belum melakukan mengkaji kualitas VCO tersebut setelah proses penggorengan. Salah satu bahan alam yang dapat dimanfaatkan dalam pembuatan VCO adalah wortel. Keuntungan dari penambahan wortel dalam VCO adalah wortel merupakan bukan jenis tanaman musiman serta penyebaran wortel di Indonesia mudah di temukan sesuai dengan hasil survei pertanian produksi tanaman sayuran di Indonesia (BPS, 1991) luas areal panen wortel nasional mencapai 13.398 hektar.

Wortel diidentifikasi mengandung senyawa karotenoid yang sangat bervariasi, terutama kandungan senyawa $\beta$-karotennya yang sangat tinggi. Senyawa karotenoid memiliki aktivitas antioksidan dan sangat bermanfaat dalam menghambat reaksi oksidasi. Hasil penelitian Momuat et al. (2011) menunjukan bahwa penambahan wortel dalam pembuatan VCO dapat menghambat reaksi oksidasi sehingga parameter bilangan peroksida lebih rendah.

VCO yang dibuat dengan metode mixing dan VCO yang dibuat dengan metode pemanasan bertahap mengandung komponen tak tersabunkan yaitu $\alpha$-tokoferol yang juga berfungsi sebagai antioksidan alami, namun demikian diharapkan VCO dan VCO wortel memiliki kualitas yang baik pada saat penggorengan. Anwar (2011) dan Musdalifah (2011).

Berdasarkan uraian, perlu dilakukan penelitian tentang kualitas VCO sebagai minyak goreng dengan adanya penambahan wortel..

\section{METODOLOGI PENELITIAN}

Penelitian ini dilaksanakan di Laboratorium Kimia Organik, Laboratorium Advance Fakultas Matematika dan Ilmu Pengetahuan Alam dan BARISTAND (Balai Riset dan Standarisasi dan Industri).

\subsection{Alat}

Alat yang digunakan dalam penelitian ini adalah pipet, gelas kimia, gelas ukur, labu takar, erlenmeyer, tabung reaksi, corong, cawan porselin, batang pengaduk, saringan, ember plastik transparan, wajan, timbangan analitik, statif, kain saring, kertas saring, kompor, deep frying.

\subsection{Bahan}

Bahan yang digunakan dalam penelitian ini adalah kelapa, wortel, asam asetat, kloroform, kalium iodida jenuh, $0.1 \mathrm{~N}$ natrium thiosulfat, larutan pati $1 \%$, etanol $95 \%$, indikator phenolftalein, natrium hidroksida $0.0991 \mathrm{~N}$, minyak sawit komersil dan minyak kelapa komersil.

\subsection{Metode}

\section{a. Pembuatan VCO pada Pemanasan Bertahap (BPTP Sulut, 2011)}

Daging kelapa diparut hingga

dihasilkan $21 \mathrm{~kg}$ kelapa. ditambahkan air 42 liter ke dalam hasil parutan kelapa dengan perbandingan 1:2. Dilakukan pemerasan selama 15 menit agar parutan kelapa tercampur dengan air. Kelapa diperas dengan bantuan saringan agar ampas kelapa tidak tercampur dengan santan yang akan dihasilkan dari pemerasan.

\section{b. Pembuatan VCO pada Pemanasan Bertahap dengan penambahan wortel (BPTP Sulut, 2011)}

Daging kelapa diparut hingga dihasilkan $21 \quad \mathrm{~kg}$ kelapa. Selajutnya ditambahkan air 42 liter ke dalam hasil parutan kelapa dengan perbandingan 1:2. Penambahan wortel pada kelapa dipakai perbandingan 40:1. Wortel yang telah dihaluskan, ditambahkan ke dalam kelapa dan air. Selanjutnya dilakukan pemerasan selama 15 menit agar parutan kelapa tercampur dengan air. Kelapa diperas dengan bantuan saringan agar ampas kelapa tidak tercampur dengan santan yang akan dihasilkan dari pemerasan.

Santan kelapa diletakkan dalam wadah plastik transparan, didiamkan selama 3 jam, santan akan terpisah menjadi tiga lapisan, yaitu lapisan atas berupa krim (kaya minyak), lapisan tengah berupa air atau skim (kaya protein) lapisan bawah berupa endapan.

Krim pada lapisan atas dipindahkan dengan menggunakan sendok besar. Selanjutnya dimasukkan ke dalam wajan yang sudah bersih, lalu panaskan di atas api dengan suhu $80^{\circ} \mathrm{C}$, Sambil krim diaduk secara kontinu, agar tidak terjadi kerak akibat krim yang hangus. Pengadukan dilanjutkan hingga tampak adanya pemisahan blondo dengan minyak, pada saat itu warna blondo masih berwarna putih. Untuk memisahkan minyak dan blondo dilakukan penyaringan menggunakan saringan dari kawat yang tahan 
panas yang dialas dengan bantuan kain saring. Minyak yang diperoleh adalah minyak belum matang atau masih mentah. Untuk mendapatkan minyak yang berkualitas, minyak yang diperoleh dipanaskan lagi pada suhu $60{ }^{\circ} \mathrm{C}$ untuk menghasilkan minyak yang bening dan mengurangi kadar air. Minyak yang telah dipanaskan didinginkan kemudian dilakukan penyaringan dengan kertas saring. Selanjutnya minyak yang diperoleh akan diuji kualitas minyak yang meliputi minyak kelapa murni (VCO), minyak kelapa dengan penambahan ekstrak wortel dan minyak sawit. Minyak yang diuji kualitas sebagai minyak goreng yaitu, bilangan peroksida, asam lemak bebas (FFA), bobot jenis, dan kadar air sebelum dan sesudah dilakukan penggorengan sebanyak 3 kali.

\section{c. Perhitungan Rendemen Hasil}

Rendemen minyak dihitung berdasarkan bobot minyak yang diperoleh $(\mathrm{g})$ dibandingkan dengan bobot kelapa parut yang digunakan $(\mathrm{g})$ dengan menggunakan rumus sebagai berikut;

$$
\begin{gathered}
\text { Rendemen hasil }(\%)= \\
\frac{\text { bobot minyak yang diperoleh }(\mathrm{g})}{\text { bobot kelapa parut }(\mathrm{g})} \times 100 \%
\end{gathered}
$$

\section{d. Penggorengan kentang dengan menggunakan VCO dan VCO dengan penambahan wortel (Sartika, 2009)}

Minyak yang sudah jadi diuji kualitasnya baik sebelum penggorengan maupun setelah penggorengan. Proses Penggorengan Menggunakan Deep Frying. Dimulai dengan memasukkan minyak kelapa murni (VCO) ke dalam ketel penggorengan sebanyak 3 liter, kemudian ketel dipanaskan hingga suhu mencapai $160^{\circ} \mathrm{C}$. Setelah itu, sebanyak 100 gram kentang siap saji komersial digoreng menggunakan Deep Frying selama 10 menit dan diaduk sebanyak 5 kali. Minyak hasil dari penggorengan pertama digoreng lagi sebanyak 3 kali. Demikian halnya dilakukan terhadap VCO dengan penambahan wortel.

\section{e. Analisis Kualitas Virgin Coconut Oil (VCO)}

Analisa kualitas dilkukan pada VCO sebelum dan sesudah penggorengan masingmasing meliputi kadar air, bobot jenis, asam lemak bebas, dan bilangan peroksida.

\section{e.1. Uji Kadar Air (Wardani, 2011)}

Ditimbang sampel $\pm 3 \mathrm{~g}$ dengan botol timbang. Dipanaskan dengan oven pada suhu $105^{\circ} \mathrm{C}$ selama 3 jam. Didinginkan dalam desikator selama 30 menit. Ditimbang botol timbang tersebut. Diulangi pemanasan dan penimbangan sampel hingga diperoleh berat konstan dengan menggunakan rumus sebagai berikut.

$$
\begin{aligned}
& \text { Kadar air }= \\
& \quad \frac{\text { berat awal }- \text { berat akhir }}{\text { berat awal }} \times 100 \%
\end{aligned}
$$

\section{e.2. Bobot Jenis (Ketaren, 1986)}

Piknometer dibersihkan dan dikeringkan, kemudian diisi dengan akuades yang telah mendidih dan didinginkan pada suhu $30^{\circ} \mathrm{C}$. Piknometer diiisi sampai air dalam bobot meluap dan tidak terbentuk gelembung udara. Piknometer ditutup dengan penutup yang dilengkapi termometer, selanjutnya direndam dalam waterbath yang bersuhu $30^{\circ} \mathrm{C}$ dan dibiarkan pada suhu konstan selama $\quad 30$ menit. Piknometer diangkat dari waterbath dan dikeringkan, Piknometer dengan isinya ditimbang. Bobot air adalah selisih bobot poiknometer dengan isinya dikurangi bobot piknometer kosong.

Minyak disaring dengan kertas saring, didinginkan sampai $30^{\circ} \mathrm{C}$, dan dimasukkan ke dalam piknometer sampai meluap dan diusahakan agar tidak terbentuk udara. Piknometer ditutup dengan penutup yang dilengkapi termometer, minyak yang meluap dan menempel diluar piknometer dibersihkan, selanjutnya piknometer direndam dalam waterbath yang bersuhu $30^{\circ} \mathrm{C}$ dan dibiarkan pada suhu konstan selama 30 menit. Piknometer diangkat dari waterbath dibersihkan dan dikeringkan dengan hati-hati. Piknometer dengan isinya ditimbang. Bobot minyak adalah selisih berat piknometer beserta isinya dikurangi berat piknometer kosong. Bobot jenis minyak pada suhu $30^{\circ} \mathrm{C}$ dengan menggunakan rumus sebgai berikut:

Bobot jenis =

$\frac{(\text { berat piknometer }+ \text { minyak }(\mathrm{g})-(\text { berat piknometer kosong }(\mathrm{g})}{\text { volume air pada suhu } 25 \mathrm{OC}(\mathrm{ml})}$

\section{e.3. Bilangan Peroksida (Ketaren, 1986)}

Sebanyak 5 g sampel dimasukkan ke dalam erlenmeyer $250 \mathrm{ml}$, ditambahkan 30 $\mathrm{mL}$ campuran pelarut yang terdiri dari $60 \%$ asam asetat glasial dan $40 \%$ kloroform. Setelah minyak larut, ditambahkan $1 \mathrm{~g}$ larutan kalium iodida jenuh sambil dikocok. 
Selanjutnya didiamkan selama tiga puluh menit dalam ruang gelap, kemudian ditambahkan $30 \mathrm{~mL}$ aquades. Kelebihan iod dititrasi dengan larutan $0,1012 \mathrm{~N}$ Natrium thiosulfat sampai warna kuning 'hampir hilang. Selanjutnya ditambahkan $0.5 \mathrm{~mL}$ larutan pati $1 \%$. Titrasi dilanjutkan sampai warna biru mulai hilang. Hasilnya dinyatakan dalam miliekuivalen per 1000 gram minyak dengan menggunakan rumus sebagai berikut.

$$
\text { Bilangan Peroksida }=\frac{\mathrm{A} \times \mathrm{N} \times 1000}{\mathrm{G}}
$$

Keterangan:

$\mathrm{A}=$ jumlah ml larutan $\mathrm{Na}_{2} \mathrm{~S}_{2} \mathrm{O}_{3}$

$\mathrm{N}=$ normalitas $\mathrm{Na}_{2} \mathrm{~S}_{2} \mathrm{O}_{3}$

$\mathrm{G}=$ berat sampel (gram)

\section{e.4. Asam Lemak Bebas (Ketaren, 1986)}

Sampel sebanyak $10 \mathrm{~g}$ dimasukkan ke dalam erlenmeyer $200 \mathrm{~mL}$, dan ditambahkan $50 \mathrm{ml}$ etanol $95 \%$. Ke dalam campuran ditambahkan 3-5 tetes indikator phenoftalein. Selanjutnya dititrasi dengan larutan standar $\mathrm{NaOH} 0.0991 \mathrm{~N}$ hingga berwarna merah muda.

Selanjutnya dihitung jumlah $\mathrm{KOH}$ yang digunakan untuk titrasi dicatat untuk menghitung kadar asam lemak bebas dengan menggunakan rumus sebagai berikut.

$$
\begin{gathered}
\text { Kadar asam lemak bebas (FFA) (\%) } \\
=\frac{\mathrm{MxAxN}}{10 \mathrm{G}} \%
\end{gathered}
$$

$\mathrm{M}=$ bobot molekul asam lemak (untuk minyak kelapa $=205$; minyak kelapa sawit=263)

$\mathrm{A}=$ volume $\mathrm{KOH}$ untuk titrasi $(\mathrm{ml})$

$\mathrm{N}=$ Normalitas larutan $\mathrm{KOH}$

$\mathrm{G}=$ berat sampel (gram)

\section{HASIL DAN PEMBAHASAN}

\subsection{Rendemen Virgin Coconut Oil (VCO)}

Rendemen merupakan rasio antara berat minyak VCO yang dihasilkan dengan berat kelapa parut yang digunakan. Pada penelitian ini, pembuatan VCO dilakukan dengan cara pemanasan bertahap menggunakan dua suhu $\left(80^{\circ} \mathrm{C}\right.$ dan $\left.60^{\circ} \mathrm{C}\right)$. Rendemen VCO dari pengolahan daging buah kelapa dengan metode pemanasan bertahap disajikan pada Gambar 1.

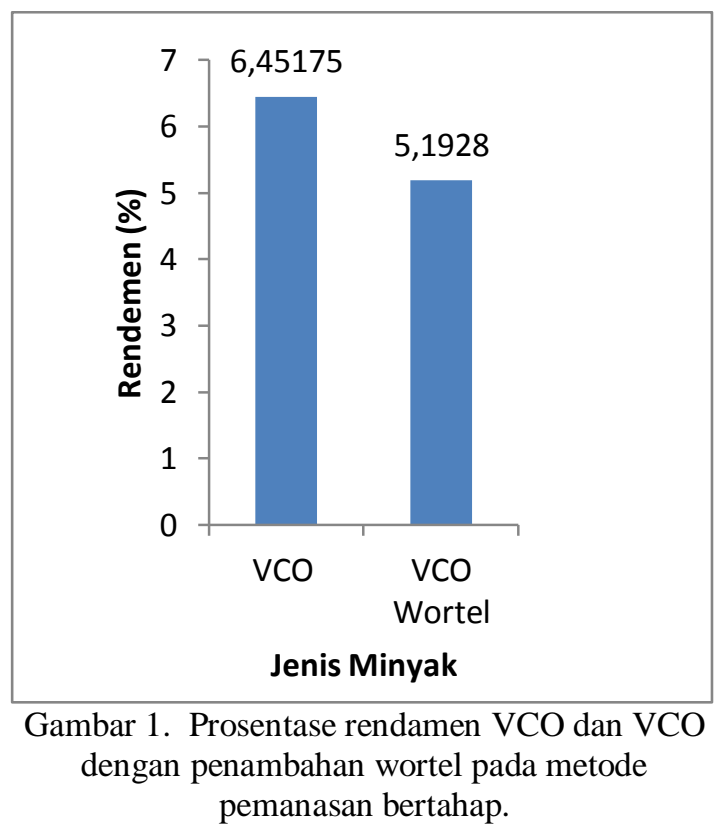

Berdasarkan Gambar 1, VCO menghasilkan rendemen yang lebih banyak dibandingkan VCO yang ditambahkan wortel. Minyak yang dihasilkan pada pembuatan VCO yang ditambahkan wortel memiliki rendemen yang lebih kecil dari VCO diduga hal ini karena wortel yang ditambahkan pada proses pembuatan VCO mengandung komponen-komponen yang dapat menghambat proses pemisahan minyak dengan air dalam emulsi santan. Namun komponen-komponen ini belum diketahui karena tidak dianalisis dalam penelitian.

Rendemen yang dihasilkan pada penelitian ini adalah $(6.45175 \%)$ untuk VCO sedangkan untuk VCO wortel adalah (5.1928\%) hal tersebut mrnunjukan bahwa rendemen VCO lebih sedikit jika dibandingkan dengan VCO yang dihasilkan oleh (Musdalifa,2011) yang mencapai 17.764\%. Hal ini disebabkan masih banyaknya santan yang tertinggal di ampas kelapa karena pemerasan santan yang tidak maksimal.

Hasil analisis kadar air dari komersil sawit, komersil kelapa dan VCO yang dibuat dengan metode pemanasan bertahap sebelum dan sesudah penggorengan dapat dilihat pada Gambar 2. 


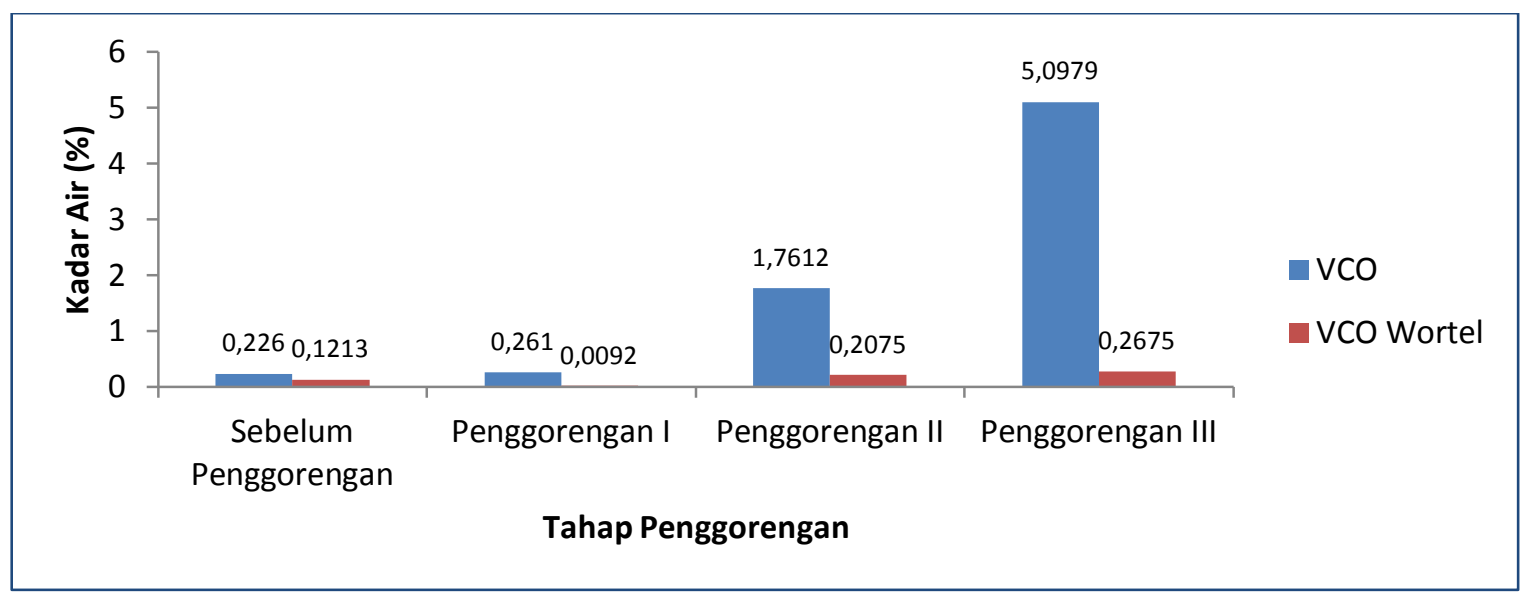

Gambar 2. Prosentase kadar air pada berbagai jenis dan perlakuan minyak

Dari gambar 2, diketahui bahwa kadar air semua sampel baik VCO, VCO dengan penambahan wortel, sebelum penggorengan masih Memenuhi standar. menurut APCC (Asian Pacific Coconut Community) standar kadar air yaitu $0.1-0.5 \%$ (Dayrit et al., 2011).

Setelah dilakukan penggorengan, kadar air dari semua sampel baik VCO dan VCO wortel dengan penambahan, menggalami kenaikkan tersebut diduga dikarenakan kentang banyak mengandung air. Pada saat penggorengan air dalam bahan terlepas dan bercampur dengan minyak sehingga kadar air sampel meningkat. air yang terlepas pada saat penggorengan diduga merupakan air bebas, dimana air ini tidak berikat dengan trigliserida.
Pada Virgin Coconut Oil terdapat dua jenis air yaitu air bebas dan air terikat. Air terikat yang terdapat pada VCO merupakan air yang terikat secara kimia berikatan dengan trigliserida. Karena sebagian dari penyusun minyak adalah trigliserida maka diduga air yang terdapat pada vco sebagian besar air terikat. Air bebas yang terdapat pada vco berada dalam keadaan bebas dan tidak berikatan dengan trigliserida (Ahmad et al., 2013).

\section{Asam Lemak Bebas}

Hasil analisis asam lemak bebas dari VCO dengan penambahan wortel dan VCO yang dibuat dengan metode pemanasan bertahap sebelum dan sesudah penggorengan dapat dilihat pada Gambar 3.

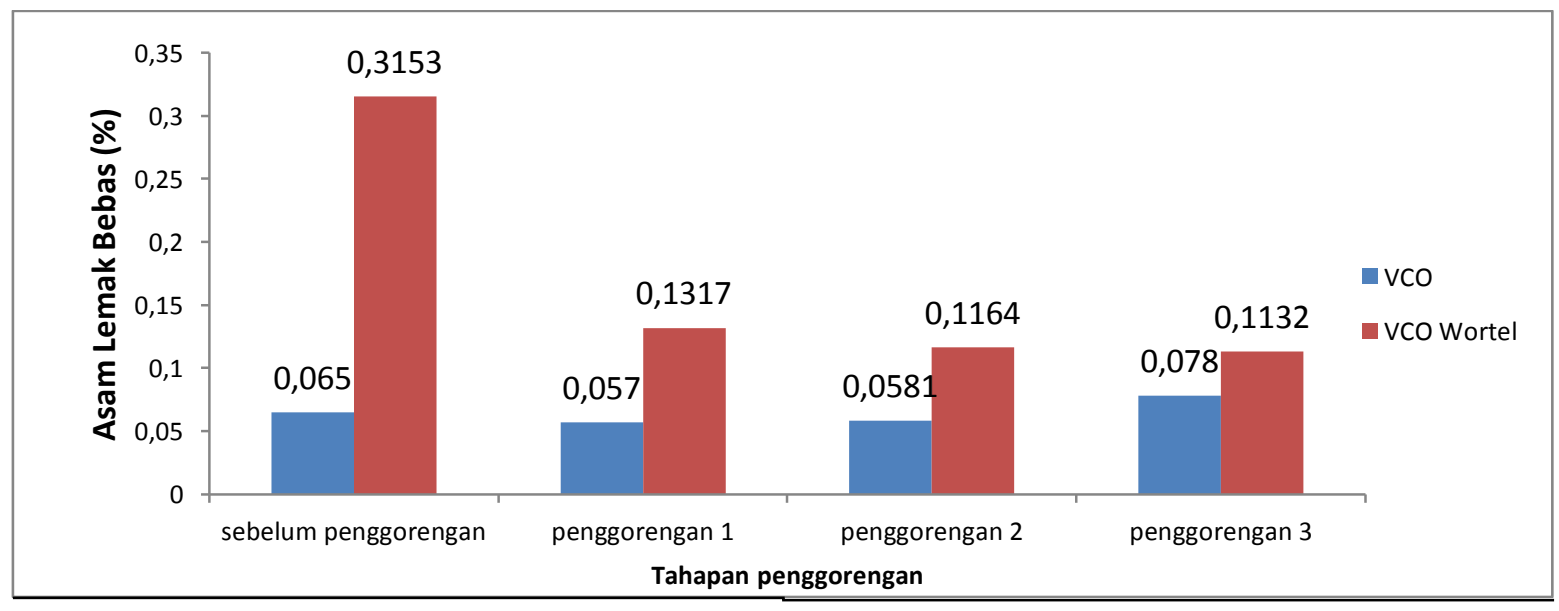

Gambar 3. Prosentase Asam lemak bebas (FFA) pada berbagai jenis dan perlakuan minyak

Dari hasil pengamatan nilai asam lemak bebas masih memenuhi standar
APCC yaitu <0.5. Nilai asam lemak pada VCO dengan penambahan wortel nilainya 
semakin menurun hal ini diduga karena adanya komponen-komponen yang terkandung dalam wortel sehingga menghambat terjadinya proses hidrolisis tersebut. Hidrolisis lemak tersebut dapat disebabkan baik oleh aktifitas enzim lipase maupun aktifitas mikroba (Buckle dalam Sidik 2013). Nilai asam lemak bebas yang tinggi inilah yang dapat menyebabkan bau tengik pada minyak yang mana menandakan bahwa minyak tersebut sudah tak layak pakai atau rusak.

\section{Bobot Jenis}

Bobot jenis dari VCO yang dibuat dengan pemanasan sebelum penggorengan dapat dilihat pada Gambar 4.

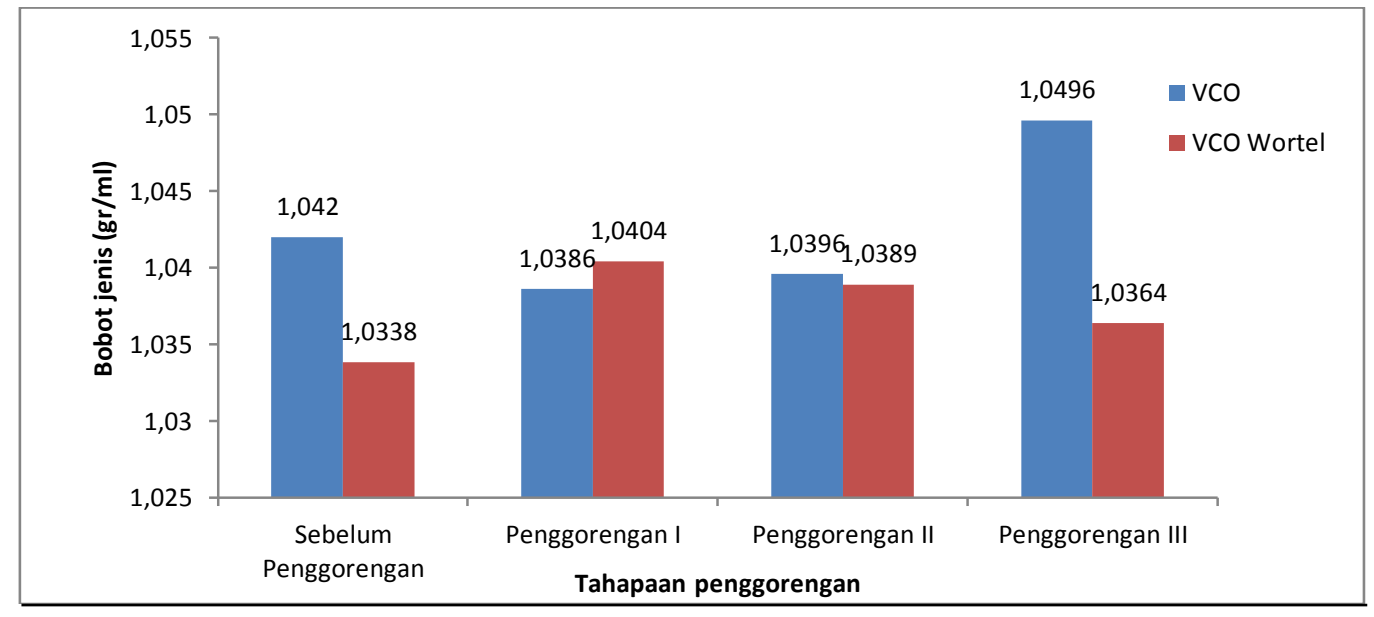

Gambar 4. Prosentase Hasil uji bobot jenis VCO, VCO wortel, komersil sawit, dan komersil kelapa sebelum dan setelah penggorengan

Bobot jenis pada VCO yang dibuat dengan penambahan wortel mengalami kenaikan hal ini juga terjadi pada VCO kontrol. Dari hasil ini dapat diketahui bahwa semua sampel tidak memnuhi standar APCC yaitu 0.915-0.920. Hal ini dikarenakan komponen asam lemak bebas yang meningkat yang menaikan nilai bobot jenis VCO (Gustani 2008), selain karena kenaikan asam lemak bebas, bobot jenis sampel juga dipengaruhi oleh kadar air dan komponen komponen lain yang terkandung dalam sampel VCO dan komersial. Seperti yang dilihat pada hasil analisis kadar air, semua sampel mengalami kenaikan kadar air dari tiap proses penggorengan.

\section{Bilangan Peroksida}

Hasil analisis bilangan peroksida dari VCO dengan penambahan wortel dan VCO yang dibuat dengan metode pemanasan bertahap sebelum dan sesudah penggorengan dapat dilihat pada Gambar 5.

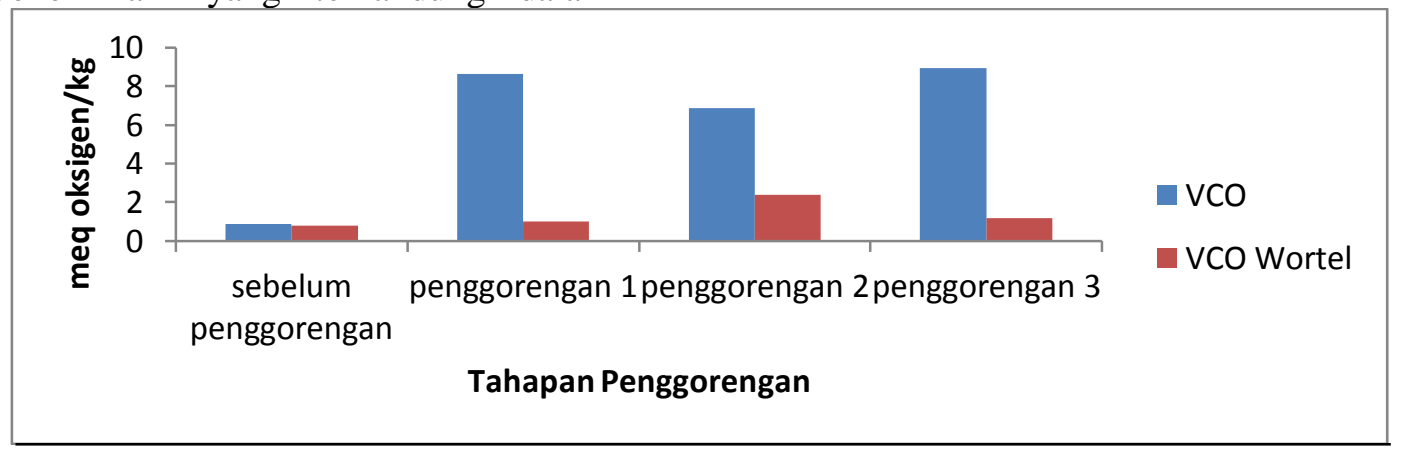

Gambar 5. Hasil uji bilangan peroksida pada VCO, VCO wortel, Minyak sawit komersial, dan Minyak kelapa komersial sebelum dan setelah penggorengan

Berdasarkan pada Gambar 5, diketahui bahwa VCO tanpa penambahan wortel bilangan peroksidanya lebih besar dibandingkan dengan VCO yang ditambahkan wortel, hal tersebut juga terjadi pada proses penggorengan 1, 2 dan 3 , 
dimana VCO wortel yang memiliki bilangan peroksida yang lebih rendah dari VCO. Bilangan peroksida dengan penambahan wortel lebih kecil dibandingkan dengan VCO menunjukkan bahwa wortel mempunyai sifat antioksidan yaitu sebagai senyawa karotenoid yang sangat bervariasi, teristimewa kandungan $\beta$-karotennya yang sangat tinggi (Andarwulan dan Koswara, 1992). Senyawa karotenoid memiliki aktivitas antioksidan dan sangat bermanfaat dalam menghambat reaksi oksidasi. Hal tersebut sesuai dengan penelitian Momuat et al. (2011) yang menyimpulkan bahwa tingkat oksidasi lipid plasma tikus yang diberi VCO mengandung ekstrak wortel lebih rendah daripada kontrol.

\section{KESIMPULAN}

Dari uji kualitas minyak yang telah dilakukan diperoleh bahwa, VCO dengan penambahan wortel memiliki kualitas yang lebih baik dibandingkan dengan VCO tanpa penambahan wortel, untuk parameter bilangan peroksida dan kadar air pada sebelum dan setelahpenggorengan tahap pertama sampai penggorengan tahap ketiga. Untuk pparameter asam lemak bebas (FFA), VCO dengan penambahan wortel tidak lebih baik namun masih memenuhi standar APCC (Asian and Pacific Coconut Community). Setelah penggorengan tahap pertama samapai penggorengan tahap ke tiga parameter bobot jenis VCO dan VCO dengan penambahan wortel tidak memenuhi standar APCC.

\section{DAFTAR PUSTAKA}

Ahmad, M. I., Lucia, C. M., Tineke, M. L., Jenny, E. A. K. 2013. Pengaruh Perbandingan Santan dan Air Terhadap Rendemen, Kadar Air dan Asam Lemak Bebas (FFA) Virgin Coconut Oil.

Anwar, F. 2011. Analisis Komponen Tidak Tersabunkan Dalam Virgin Coconut Oil (VCO) Yang Dibuat Dengan Metode Mixing [Skripsi]. FMIPA UNSRAT.
APCC, 2005. APCC Standar For Virgin Coconut Oil.

http://www.apccsec.org/standars.htm. [1januari 2011]

Asy'ari, M., dan B. Cahyono. 2006. PraStandarisasi: Produksi dan Analisis Minyak Virgin Coconut Oil (VCO). JSKA. 9: 1-9.

BPS (1991), Survei Pertanian Produksi Tanaman Sayuran.

Dayrit, F. M., Ian, K. D. D., Melodina, F. V., Jaclyn, E. R. S., Mark, J. M. G., Blanca, J. V. 2011. Quality Characteristic of Virgin Coconut Oil: Comprosions With Refined Cocunut Oil. Pure Appl. Chem. 83: 1789 1799.

Gugule, S. dan F. Fatimah. 2010. Karakterisasi Virgin Coconut Oil (VCO) Rempah. Chem. Prog. 2: 104.

Gustiani, 2008. Studi Ekstraksi Analisis Minyak Lengkeng. [skripsi]. F-MIPA UI, Jakarta

Kataren, S., 1986. Pengantar Teknologi Minyak dan Lemak Pangan. UI Press, Jakarta.

Langingi, R., L. I. Momuat., M. G. Kumaunang. 2012. Pembuatan Sabun Mandi Padat dari VCO yang Mengandung Karotenoid Wortel. Jurnal Mipa Unsrat Online. 1: 20-23

Mokoginta, Y. (2002). Kajian Beberapa Sifat Mutu Minyak Kelapa yang diolah Melalui Beberapa Metode Pengolahan Secara Basah. [Skripsi]. Fakultas Pertanian Unsrat Manado.

Momuat, L. I., Meiske, S. S., Ni, P. P. Pengaruh VCO Mengandung Ekstrak Wortel Terhadap Peroksida Lipid Plasma. Jurnal Ilmiah Sains. 11: $296-301$.

Musdalifa. 2011. Analisis Komponen Tidak Tersabunkan Dari VCO Yang Dibuat Dengan Metode Pemanasan Bertahap. [Skripsi]. FMIPA UNSRAT. 
Pontoh, J., Subakti, Br. M., dan Papilaya, M. 2008. Kualitas Virgin Coconut Oil Dari Beberapa Metode Pembuatan. Chem.Prog. 1: 60-65.

Ruku, S., 2007. Teknologi Pengolahan Minyak Kelapa Murni. Bul. Teknologi dan Informasi. 64-73.

Rukmana, R. 1995. Bertanam Wortel. Kanisius. Yogyakarta.

Sartika, D. A. R. 2009. Pengaruh Suhu Dan Lama Proses Menggoreng (Deep Frying) Terhadap Pembentukan Asam Lemak Trans. Makara, Sains. 13: 2328.

Setiaji, B. dan S. Prayugo., 2006. Membuat VCO Berkualitas Tinggi, Penebar Swadaya, Jakarta.

Sidik, L. S., F. Fatimah., M. S. Sanggi. 2013. Pengaruh Penambahan Emulsifier dan Stabilizer

Terhadap Kualitas Santan Kelapa. Jurnal Mipa Unsrat Online. 2: 79-83

Sukartin, K. J. dan Sitanggang, M. 2005. Gempur Penyakit dengan VCO. Edisi1. AgroMedia Pustaka. Jakarta.
Susilowati. 2009. Pembuatan Virgin Coconut Oil Dengan Metode Penggaraman. Jurnal Teknik Kimia. 3: 247-251.

SNI-7381-2008. 2008. Minyak Kelapa Virgin (VCO). Dewan Standar Nasional Indonesia. Jakarta.

Syah, A. N. A. 2005. Perpaduan Sang Penakluk Penyakit: $V C O+$ Buah MInyak Merah. Agromedia Pustaka. Jakarta.

[USDA] United States Department Of Agriculture. 2007. USDA National Nutrient Database for Standard Reference.http://www.nal.usda.gov/fn ic/foodcomp/cgibin/list_nut_edit.pl. [November 2013].

Wardani, I.E., 2007. Uji Kualitas VCO Berdasarkan Cara Pembuatan dari Proses Pengadukan Tanpa Pemancingan dan Proses Pengadukan Tanpa Pemancingan. [skripsi]. UNNES, Semarang.

Winarno, F. G. 2002. Kimia Pangan dan Gizi. Gramedia, Jakarta. 